\title{
PPPUD Produk Olahan Pisang Lokal Khas NTT Berbasis Inovasi Teknologi Semi Otomatis
}

\author{
Christa Elena Blandina Bire \\ TKJ, Politeknik Negeri Kupang
}

Janri Delastriani Manafe

Adm Bisnis, Politeknik Negeri Kupang

\section{Petrisia Widyasari Sudarmadji \\ TKJ, Politeknik Negeri Kupang}

\author{
Edwin Pieter Dominggus \\ Hattu \\ Teknik Otomotif, Politeknik Neger \\ Kupang
}

Yohanes Suban Peli

Teknik Elektronika, Politeknik Negeri Kupang

\begin{abstract}
PPPUD is a regional flagship product development program in the form of community service with uniqueness / characteristics produced by certain business groups. Legit Sari joint venture group (KUBE) in Nunleu village - Oebobo District - Kupang - East Nusa Tenggara is a partner of kupang state polytechnic lecturer team in community service activities, whose business has been running for approximately five years and engaged in local food processing business. The problems encountered in this partner are production process, product innovation, facility improvement to support product quality. The methods used in the implementation of community service are: technology transfer method and knowledge method. The solution to the problem that targets the activity is: Improvement of the speed of the production process with the application of mechanization of dodol stirrer and mechanization of ergonomic dodol slicer; improvement of production quality with the innovation of adding flavor variants to dodol; improvement of labelling and packaging/packing models to improve the hygienic and quality of dodol products; procurement of production support facilities and all these activities are th end with an evaluation in the form of monitoring the work of partners with a team of lecturers of Kupang State Polytechnic.
\end{abstract}

Keywords: community service; mechanization; dodol; Legit Sari

\begin{abstract}
Abstrak
PPPUD merupakan program pengembangan produk unggulan daerah dalam bentuk pengabdian masyarakat dengan keunikan/ciri khas yang di hasilkan oleh kelompok usaha tertentu. Kelompok usaha bersama (KUBE) Legit Sari di desa Nunleu - Kecamatan Oebobo - Kupang - Nusa Tenggara Timur adalah mitra kerja tim dosen Politeknik Negeri Kupang pada kegiatan pengabdian masyarakat, yang mana usahanya sudah berjalan kurang lebih lima tahun dan bergerak pada usaha olahan pangan lokal. Permasalahan yang di temui pada mitra ini adalah proses produksi, inovasi produk, pembenahan fasilitas untuk menunjang kualitas produk. Metode yang di gunakan dalam pelaksanaan pengabdian kepada masyarakat ini adalah : metode transfer teknologi dan metode knowledge. Solusi permasalahan yang menjadi target kegiatan adalah : Perbaikan kecepatan proses produksi dengan penerapan mekanisasi pengaduk dodol dan mekanisasi pengiris dodol yang ergonomis; perbaikan kualitas produksi dengn inovasi penambahan varian rasa pada dodol; perbaikan model labelling dan pengemasan/pengepakan untuk meningkatkan higienis dan kualitas produk dodol; pengadaan fasilitas penunjang produksi dan semua kegiatan ini di akhiri dengan evaluasi berupa monitoring hasil kerja dari mitra dengan tim dosen Politeknik Negeri Kupang.
\end{abstract}

Kata kunci: pengabdian masyarakat; mekanisasi; dodol; legit sari

\section{Pendahuluan}

Kelompok Usaha Bersama (KUBE) Legit Sari berlokasi di Jl. Banteng RT.22/RW.04 Desa/Kelurahan. Nunleu - Kupang - Nusa Tenggara Timur merupakan unit usaha makanan yang berbasis olahan hasil pertanian serta kue-kue, dimana semua proses di kerjakan oleh owner dan enam orang pekerja tetap yaitu ibu rumah tangga di sekitar lokasi mitra. Mitra Legit Sari di dirikan 
pada tahun 2013 dan menjadi kelompok usaha yang kreatif dan mandiri sehingga masih memungkinkan untuk di tingkatkan kapasitas usahanya. Mitra Legit Sari memiliki omset pendapatan bersih rata-rata pertahun Rp. 155.520.000/tahun. Produk yang di hasilkan berupa dodol pisang kulit hijau khas NTT mampu bersaing dan menjadi produk berciri khas NTT. Pertumbuhan Mitra Legit Sari secara langsung sudah mampu memacu pertumbuhan pemasaran melalui distribusi yang sudah menembus beberapa supermarket dan toko oleh-oleh di kota Kupang. Adapun ringkasan eksiting mitra Legit Sari yang meliputi keseluruhan aspek bisnis akan di uraikan detil sebagai berikut :

a) Bahan Baku

Dodol terbagi dalam dua jenis yaitu, dodol yang terbuat dari beras ketan dan dodol yang terbuat dari buah-buahan (Haryadi, 1998)). Dan dodol yang di produksi oleh Legit Sari ini menggunakan bahan baku buah-buahan yaitu pisang lokal kulit hijau. Suplai bahan baku produk berupa pisang lokal kulit hijau banyak di temui dengan harga yang relatif murah dan merupakan inovasi dodol berbahan baku buah (Satuhu \& Sunarmani, 2004) . Demikian maka bahan baku tidak menjadi hambatan dalam proses PPPUD KUBE Legit Sari

b) Produksi

Kapasitas produksi KUBE Legit Sari terdiri dari berbagai komoditi berbasis olahan hasil pertanian, tetapi pada kegiatan pengabdian skim PPPUD kali ini hanya di fokuskan pada produk dodol pisang lokal kulit hijau berdaya tahan lama. Jumlah produksi yang di hasilkan perbulan adalah 720 bungkus / 18.000 buah dodol dengan varian rasa berbeda yaitu cokelat dan original. Kontrol kualitas produk dilakukan mulai dari tahap seleksi bahan baku, selama proses produksi hingga menjadi produk dodol, sehinga ketika akan di kirim ke costumer ataupun di pasarkan sudah terjamin kualitas mutu produk sesuai dengan standar baku yaitu tidak terdapat cacat bahan atau produk. Nilai investasi telah berkembang secara signifikan dari nilai Rp.70.000.000,- pada tahun 2013, pada tahun 2017 berkembang menjadi rata-rata Rp.155.520.000,- dengan uraian sbb :

Produksi per/minggu berjumlah 180 bungkus @Rp.18.000,- = @Rp.3.240.000,-

Produksi per/bulan 4 x Rp. 3.240.000,- = Rp. 12.960.000,-

Produksi per/tahun 12 x Rp. 12.960.000,- = Rp. 155.520.000,-

c) Proses

Pengerjaan pembuatan dodol pisang kulit hijau, semuanya menggunakan tangan (manual) dan alat pendukung sederhana dengan teknik yang tradisional. Produk yang dihasilkan, di buat dengan ketelitian, bahan baku yang berkualitas dan cita rasa yang khas sehingga jaminan mutu produk tidak menjadi hambatan dalam produk yang dihasilkan. Adapun gambar di bawah ini mendiskripsikan proses pembuatan dodol pisang kulit hijau

d) Produk

Produk yang di hasilkan oleh KUBE Legit Sari adalah :

$>$ Dodol pisang kulit hijau rasa cokelat 360 bks (9000 buah/bulan)

> Dodol pisang kulit hijau rasa original 360 bks (9000 buah/bulan)

e) Distribusi Produk Hingga Ke Tangan Konsumen

Pola distribusi produk hingga ke tangan konsumen masih secara konvensional yakni : konsumen yang sudah mengetahui alamat rumah poduksi biasanya langsung mendatangi rumah produksi dan memesan langsung sekaligus melihat langsung model-model produk dan bahan baku yang tersedia. Pola distribusi lainnya adalah dengan menjual langsung pada gerai yang berlokasi pada MALL sehingga mampu menjangkau pengunjung secara luas.

f) Manajemen

KUBE Legit Sari merupakan perusahaan perorangan, namun telah memiliki produksi 
dan kualitas produk yang di hasilkan berupa : Sertifikasi pangan industri rumah tangga, Sertifikat Halal, Sertifikat Merek dari Kemenkumham. Untuk pola manajemen keuangan masih menggunakan pola tradisional yang sederhana dan pola pembukuan yang dilakukan untuk merekap pesanan dan omset bulanan masih menggunakan pembukuan tulis tangan sehingga sangat dimungkinkan untuk di perbaiki dan dibina proses pembukuan secara komputerisasi sehingga data yang direkap aman secara penyimpanan (storage) dan lebih efisien karena menggunakan berkas elektronik.

g) Pemasaran (Teknik Pemasaran, Harga Jual Produk, Konsumen)

Teknik pemasaran produk KUBE Legit Sari sudah meliputi jangkauan regional karena separuh produk ada yang masuk pada gerai mall sehingga berpotensi untuk di kembangkan lebiah luas lagi hingga ke manca negara terutama Negara terdekat yaitu Timor Leste dan Australia. Pesatnya pemasaran KUBE Legit Sari didukung oleh social media seperti Facebook dan Instagram sehingga di asumsikan bahwa KUBE Legit Sari membutuhkan suatu aplikasi online berupa e-commerce untuk pemasaran secara online lebih terpadu dan terkontrol. Harga produk dodol pisang kulit hijau adalah sbb : Dodol pisang varian rasa cokelat Rp. $18.000,-/$ bks dan dodol pisang varian rasa original Rp. 18.000,-/bks.

h) SDM ( Sumber Daya Manusia )

Tenaga SDM cukup berkualifikasi karena mereka telah di latih sebelum perekrutan menjadi tenaga kerja tetap maupun binaan tenaga kerja borongan. Jumlah tenaga kerja tetap 6 orang dengan pendidikan terakhir SMP, SMA, dan putus sekolah. Untuk meningkatkan keterampilan berpikir SDM maka dibutuhkan pembinaan training untuk mengembangkan produk lebih bervariasi dan diversifikasi.

i) Sarana

Fasilitas sarana ruang administrasi, ruang produksi, ruang penyimpanan, showroom, akses ke jalan raya, listrik dan telekomunikasi :

$>$ Ruang administrasi $4 \mathrm{~m}^{2}$

$>$ Ruang produksi $8 \mathrm{~m}^{2}$

$>$ Ruang penyimpanan $4 \mathrm{~m}^{2}$

$>$ Showroom $4 \mathrm{~m}^{2}$

$>$ Akses ke jalan raya $2 \mathrm{~m}$

$>$ Listrik $1300 \mathrm{VA}$

$>$ Telekomunikasi menggunakan telepon dan handphone dengan jaringan internet

j) Finansial (Modal, Cash-flow, IRR)

Nilai investasi telah berkembang pesat dari nilai Rp.70.000.000,- pada tahun 2013, pada tahun 2017 berkembang menjadi Rp.155.520.000,- Jumlah omset perbulan ratarata Rp. Rp. 12.960.000,- dan total omset bersih yang di terima sebagai keuntungan perbulan berkisar Rp. 50.275.000,-

Berdasarkan uraian diatas, maka dapat dilakukan identifikasi permasalahan pada aspek teknis dan administratif sebagai berikut :

Tabel 1. Permasalahan Mitra

\begin{tabular}{lll}
\hline Aspek & & \multicolumn{1}{c}{ Permasalahan Mitra } \\
\hline & Bahan Baku & Tidak Masalah \\
& Produksi & Tidak Masalah \\
& Proses & Kecepatan Produksi \\
& Produksi & Mekanisasi Produksi \\
\hline
\end{tabular}




\begin{tabular}{ccl}
\hline \multirow{2}{*}{ Teknis } & & Metode Produksi \\
& Perlu Keseragaman Volume dan \\
& & Bentuk Dodol \\
& Produk & Perlu Perbaikan Packaging dan \\
& Pengemasan Yang Baik \\
& Perlu Diversifikasi Varian Rasa \\
& Perlu Pelatihan Manajemen \\
& Keuangan dan Manajemen \\
& SDM & Kewirausahaan \\
& & Peningkatan Jumlah Pekerja \\
& Peningkatan Skill SDM \\
& Penataan Ruang Showroom \\
& Penataan Ruang Produksi \\
Administratif & Fasilitas & Penataan Ruang Penyimpanan \\
\hline
\end{tabular}

\section{Metode Pelaksanaan}

Pengabdian kepada masyarakat merupakan upaya pemanfaatan dan pengelolahan sumber daya masyarakat (SDM), dalam hal ini adalah mitra "Legit Sari" secara lebih aktif dan efisien. Pemberdayaan ditujukan bagi kemampuan seseorang, khususnya kelompok lemah dan rentan sehingga mereka punya kemampuan untuk memenuhi kebutuhan dasarnya sehingga mereka mampu untuk terbebas dari kebutuhan dasar tersebut; menunjukkan sumber-sumber produktif yang memungkinkan mereka dapat meningkatkan pendapatannya dan memperoleh barang dan jasa yang mereka butuhkan; berpartisipasi dalam proses pembangunan dan keputusan-keputusan yang mempengaruhi mereka(Ahfan et al., 2015) (Mustanir et al., 2019) dan PRA sebagai pendekatan partisipatif dan metode yang menekankan pengetahuan lokal dan memungkinkan mitra untuk melakukan penilaian, analisis dan perencanaan mereka sendiri. Oleh karena itu tim dosen pengusul memformulasikan metode pelaksanaan yang telah di lakukan dalam pengabdian kepada masyarakat ini adalah :

1) Metode transfer teknologi

$\checkmark$ Modifikasi

Metode ini di gunakan untuk lebih memaksimalkan kapasitas suatu alat penunjang/mesin yang akan di transfer sesuai dengan kebutuhan mitra. Metode ini di gunakan dalam pembuatan/ mekanisasi pengiris dodol

$\checkmark$ Pembelian

Metode ini digunakan agar lebih efisien baik biaya maupun waktu, hal ini dilakukan karena mesin/alat yang di butuhkan oleh mitra sudah tersedia banyak di pasaran dengan berbagai pilihan merek

2) Metode transfer knowledge

$\checkmark$ Ceramah

Metode ceramah di gunakan dalam seluruh kegiatan pelatihan yang akan dilaksanakan pada program pengabdian masyarakat ini, yaitu dalam proses penyampaian, materi pelatihan

$\checkmark$ Demonstrasi

Metode demonstrasi digunakan baik dalam kegiatan pelatihan maupun dalam proses menjelaskan cara pengoperasian mekanisasi/ alat pengaduk dodol dan pengiris dodol, dan pengoperasian perawatan / maintenance. Penggunaan metode demonstrasi ini lebih memberikan kemudahan kepada mitra ( para pekerja ) dalam memahami materi yang di sampaikan, sehingga mitra lebih cepat dalam menyerap/memahami materi yang di sampaikan 
$\checkmark$ Diskusi

Metode diskusi di gunakan dalam seluruh kegiatan pelatihan. Dengan adanya diskusi sebagai media komunikasi dua arah antara pemateri dan mitra ( para pekerja ). Di samping itu, mitra langsung dapat menanyakan hal-hal yang belum di pahaminya kepada pemateri, sehingga materi yang di jelaskan dapat di terima atau di pahami dengan optimal oleh mitra

$\checkmark$ Praktik

Metode praktik digunakan dalam kegiatan pelatihan maupun dalam proses menjelaskan cara pengoperasian mekanisasi/ alat pengaduk dodol dan pengiris dodol, serta pengoperasian perawatan / maintenance. Setelah pemateri menjelaskan dan mendemonstrasikan materi pelatihan, kemudian mitra ( para pekerja ) di persilahkan praktik langsung dan dapat mengaplikasikan materi yang telah di dapatkan.

3) Metode pemantauan perkembangan mitra

$\checkmark$ Metode yang digunakan dalam rangka proses pemantauan perkembangan mitra adalah observasi. Observasi di lakukan untuk memantau perkembangan mitra terkait penambahan tenaga kerja dan peningkatan produktivitas serta peningkatan omset yang di dapatkan oleh mitra.

\section{Hasil dan Pembahasan}

Pelaksanaan kegiatan pengabdian kepada masyarakat skim PPPUD ini , sudah mampu menjawab permasalahan mitra dan terfokus pada 2 aspek penting sesuai solusi dan luaran yang di usulkan yaitu aspek teknis dan aspek administrasi. Hal ini merupakan penerapan alih teknologi dari hasil penelitian untuk meningkatkan efisiensi biaya produksi maupun waktu produksi suatu produk sehingga akan meningkatkan nilai keuntungan(Ngafifi, 2014) Mitra Legit Sari berpartisipasi aktif dalam proses pelaksanaan PPPUD sebagai mitra penerima temuan teknologi yang di usulkan dan diterapkan serta pengadaan fasilitas sebagai penunjang produktifitas, berdasarkan analisis kebutuhan dan perancangan yang di observasi langsung oleh tim pengusul PPPUD Perguruan Tinggi Politeknik Negeri Kupang. Adapun uraian hasil yang telah di capai adalah sebagai berikut :

1) Aspek Teknis

$>$ Adanya perbaikan kemasan packaging dan desain model label yang menarik serta higienis dengan pengadaan kemasan pouch alumanium foil, labeling, dan pengadaan paper bag. Dengan demikian, permasalahan desain produk teratasi dan menghasilkan pengemasan produk yang lebih menarik dan berkualitas sehingga mampu menaikkan daya saing jual produk.

> Adanya penambahan varian rasa vanila dan caramel serta crunchy. Dengan adanya diversifikasi varian rasa maka permasalahan produk dapat teratasi karena produk tidak monoton pada satu jenis varian saja.

2) Aspek Administratif

> Adanya pengadaan mekanisasi pemotong dodolan sejumlah 1 unit, sehingga permasalahan fasilitas produksi telah teratasi karena mekanisasi pemotong dodolan tersebut mampu menunjang proses produksi dodol menjadi lebih efisiensi dari segi waktu dan tenaga kerja secara signifikan.

> Adanya pengadaan beberapa fasilitas penunjang pada ruang penyimpanan, yang terutama adalah media penyimpanan seperti etalase sehingga mitra memiliki ruang penyimpanan yang bersih, rapi dan tertata secara ergonomis. 
Di bawah ini adalah gambar, luaran yang di capai/di terapkan kepada mitra yaitu mekanisasi pemotong dodolan,,perbaikan packaging, labeling, fasilitas penunjang ruang penyimpanan dan perawatan teknologi yang di terapkan :

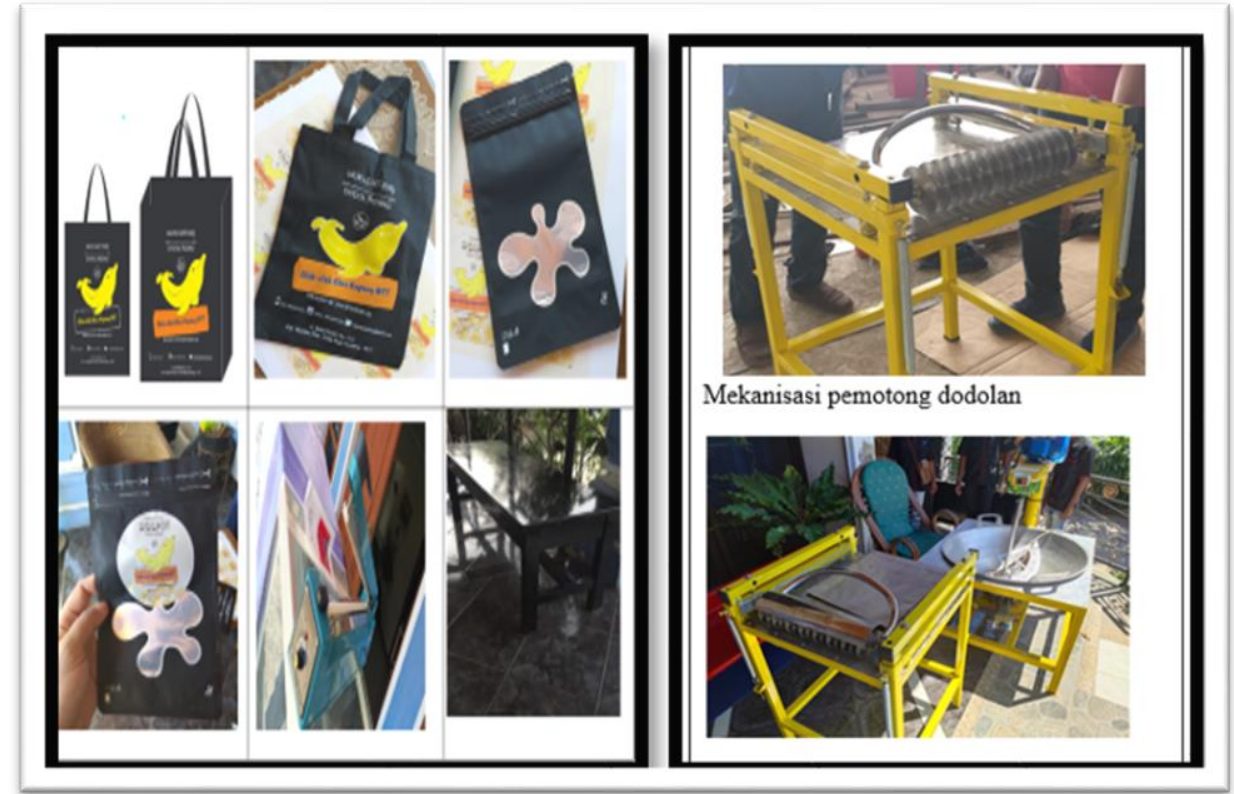

Gambar 1. Luaran kegiatan

Adapun dampak ekonomi dan sosial yang di peroleh pada kegiatan PPPUD ini, di sajikan pada tabel di bawah ini :

Tabel 2. Dampak Ekonomi dan Sosial

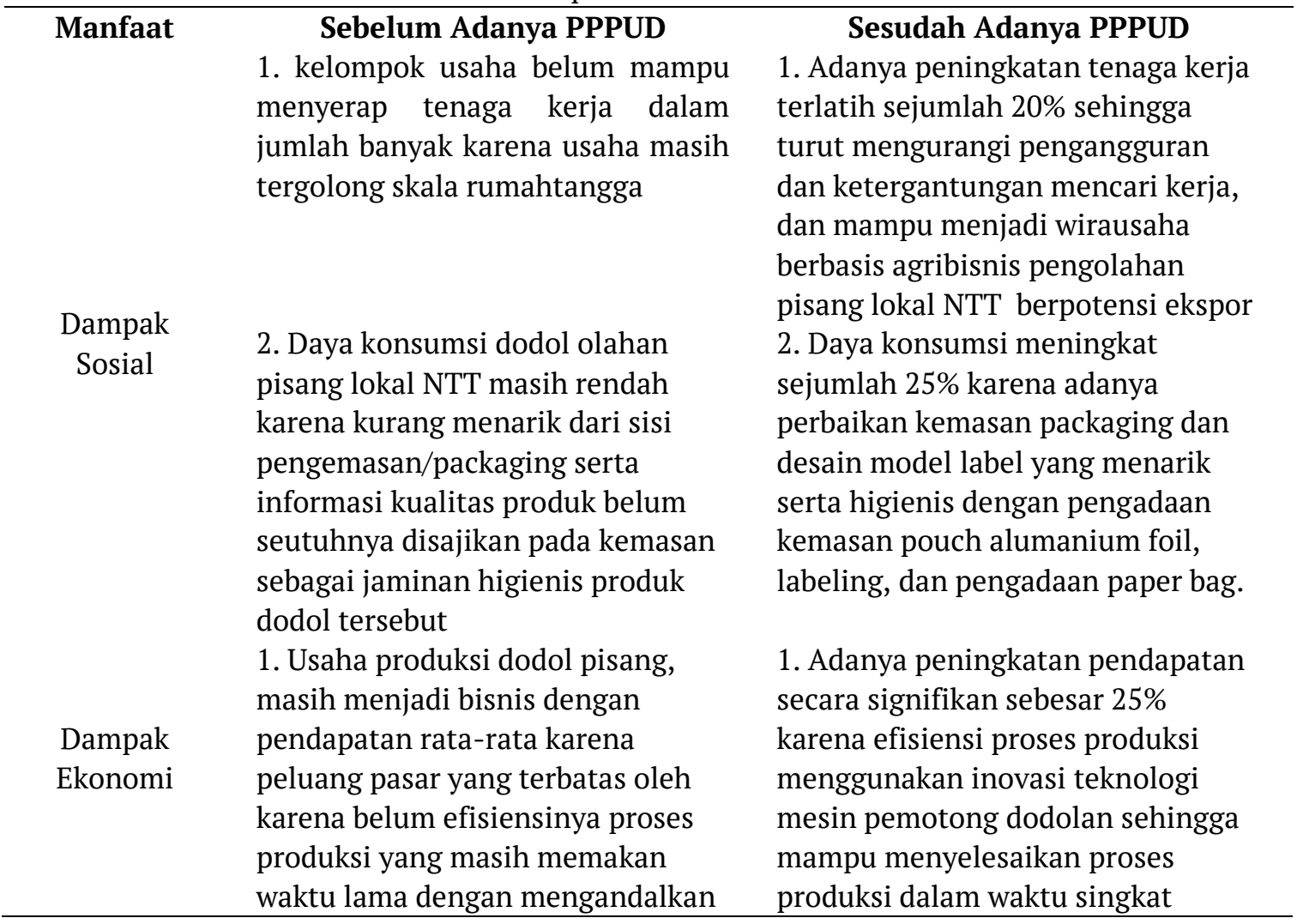


Selain uraian di atas, ada beberapa faktor yang menghambat pelaksanaan kegiatan pengabdian kepada masyarakat skim PPPUD pada tahun ini adalah :

$\checkmark \quad$ Keterbatasan waktu pelaksanaan pengabdian oleh karena kondisi pandemi COVID-19 yang mengharuskan semua masyarakat mematuhi protokol kesehatan termasuk mitra dan tim pengusul Perguruan Tinggi. Adanya batasan/larangan agar tetap bekerja dari rumah, membuat tim pengusul beserta tim teknisi baru bisa mengerjakan pengadaan alat pada bulan juli. Selain itu, area wilayah mitra, merupakan zona tidak aman di karenakan salah satu keluarga yang meninggal dunia akibat virus COVID-19 dan penyintas COVID-19 berada dalam satu keluarahan yang sama dengan tempat tinggal mitra sehingga proses uji coba alat, koordinasi, pelatihan dan serah terima alat baru bisa terselenggara pada bulan agustus 2020

$\checkmark$ Mitra bersama tim-nya belum memiliki pengetahuan awal tentang pengoperasian dan perawatan mekanisasi pemotong dodolan yang di terapkan untuk menunjang proses produksi

$\checkmark \quad$ Daya tangkap para peserta (mitra dan tim-nya) yang bervariasi, ada yang cepat namun juga ada yang lambat sehingga waktu yang di gunakan kurang maksimal dan butuh pendampingan sementara oleh tim Perguruan Tinggi

$\checkmark$ Rendahnya kesadaran aspek kesehatan dan keselamatan kerja (K3), dalam mengoperasikan mesin sehingga butuh pemahaman dan pengetahuan serta pelatihan penerapan K3 dalam bidang mekanisasi

\section{Kesimpulan}

1. Kualitas hasil produksi Mitra sudah memenuhi syarat/layak di ekspor ke negara terdekat seperti Timor leste seiring meningkatnya kapasitas produksi dan diversifikasi varian rasa produk dan serta mitra mengalami peningkatan omzet rata-rata $20-30 \%$.

2. Proses produksi lebih efisien dari segi waktu dan produk yang di hasilkan mampu berdaya saing oleh karena perbaikan packaging dan sertifikasi halal sebagai jaminan kualitas mutu produk

3. Kelompok usaha bersama (KUBE) Legit Sari menjalankan usahanya berbasis inovasi teknologi Politeknik Negeri Kupang

\section{Ucapan terimakasih}

Terimakasih kepada Direktorat Riset dan Pengabdian Masyarakat, Direktorat Jenderal Penguatan Riset dan Pengembangan Kementerian Riset, Teknologi, dan Pendidikan Tinggi Republik Indonesia atas bantuan pendanaan dan kesempatan yang diberikan kepada kami dalam mengikuti Hibah Program Pengembangan Produk Unggulan Daerah (PPPUD) 2020

\section{Daftar Pustaka}

97361-ID-modifikasi-proses-pembuatan-dodol.pdf. (n.d.). Retrieved November 27, 2020, from https://media.neliti.com/media/publications/97361-ID-modifikasi-proses-pembuatandodol.pdf

Ahfan, R., Asrori, A., \& Sipahutar, H. (2015). Pemberdayaan Masyarakat pada Program PNPM MP, Desa Peradaban, CSR dan Posdaya (Konteks Lahirnya UU No. 6 Tahun 2014). Jurnal Bina 
Praja: Journal of Home Affairs Governance, 7(1), 89-100. https://doi.org/10.21787/jbp.07.2015.89-99

Mustanir, A., Barisan, B., \& Hamid, H. (2019). Participatory Rural Appraisal As The Participatory Planning Method Of Development Planning. https://doi.org/10.13140/RG.2.2.26000.87049

Ngafifi, M. (2014). KEMAJUAN TEKNOLOGI DAN POLA HIDUP MANUSIA DALAM PERSPEKTIF SOSIAL BUDAYA. Jurnal Pembangunan Pendidikan: Fondasi Dan Aplikasi, 2(1), Article 1. https://doi.org/10.21831/jppfa.v2i1.2616

Satuhu, \& Sunarmani. (2004). Membuat Aneka Dodol Buah. Penebar Swadaya.

\section{Afiliasi:}

Christa Elena Blandina Bire ${ }^{(*)}$, Petrisia Widyasari Sudarmadji

Prodi Teknik Komputer dan Jaringan, Politeknik Negeri Kupang

E-mail: christa.eren@gmail.com, petrisia.pnk@gmail.com

Edwin Pieter Dominggus hattu

Prodi Otomotif, Politeknik Negeri Kupang

E-mail: edwinhattu10@gmail.com,

Janri Delastriani Manafe

Prodi Administrasi Bisnis' Politeknik Negeri Kupang

E-mail: janrimanafe_yahoo.co.id

Yohanes Suban Peli

Prodi Elektronika ${ }^{(5)}$, Politeknik Negeri Kupang

E-mail :yohanessuban@yahoo.com 